\title{
Juvenile idiopathic arthritis: the transition to adulthood
}

\author{
Susana Fernandes ${ }^{1}$, José António Melo Gomes ${ }^{*}$, Sónia Melo Gomes ${ }^{1}$, Fernando Martins ${ }^{2}$ \\ From 21st European Pediatric Rheumatology (PReS) Congress \\ Belgrade, Serbia. 17-21 September 2014
}

\section{Introduction}

Juvenile Idiopathic Arthritis (JIA) is term used to classify a group of heterogeneous pediatric rheumatic diseases. Many of these conditions remain active until adulthood and when patients start to be followed by adult Rheumatologists there may arise some classification problems once AIA (Adult Idiopatic Arthritis) does not exist! Many published papers regarding the transition of JIA into adulthood miss this point.

\section{Objectives}

Our aim is to analyze the characteristics of 206 JIA patients, currently in their adulthood, that have been followed, in most of their disease, by the same Rheumatologist with a follow-up time superior to 30 years in some cases.

\section{Methods}

This study includes 206 patients currently in adult age from a sample of 369 JIA patients, continuously followed by the first author in the Children, Adolescent and Young Adult Rheumatology Outpatients Clinic at IPR and Private Practice. All these patients are registered in REUMA.PT, the National Registry for rheumatic diseases of the Sociedade Portuguesa de Reumatologia. The 2010 EULAR/ACR Criteria1 for the classification of RA and the ASAS Criteria for Classification of Axial2 and Peripheral3 Spondyloarthritis were used.

\section{Results}

The group included 126 female and 80 male patients, with a mean age of $30.0+/-11.0$ years, having mean disease duration of $21.5+/-11.3$ years. The presentation forms and definitive diagnosis are listed below. Sixty three of these patients are in complete and prolonged off therapy remission. 112 patients were treated with methotrexate, 42 are or were previously treated with biological agents, and 33 had been subjected to intraarticular injections (triamcinolone hexacetonide). Other aspects concerning therapy, morbidity and mortality

Table 1

\begin{tabular}{|c|c|c|c|}
\hline Initial presentation & Number of patients & Current diagnosis & Number of patients \\
\hline Oligo persistent & 58 & Still's Disease & 34 \\
\hline Oligo extended & 31 & Rheumatoid Arthritis & 24 \\
\hline Poli FRlgM + & 17 & Axial Spondylarthritis & 14 \\
\hline Poli FRlgM - & 23 & Perypheral Spondylarthritis & 39 \\
\hline Systemic & 34 & Reactive arthritis & 2 \\
\hline Arthritis/Entesitis & 30 & Psoriatic Arthritis & 9 \\
\hline Psoriatic arthritis & 7 & Inflammatory Bowel Disease Arthropathy & 11 \\
\hline Inflammatory bowel disease & 6 & Oligo/ANA+ with Chronic Uveitis & 18 \\
\hline Ocular manifestations & & Other & 16 \\
\hline Uveitis & 25 [22 Chronic + 3 Acute] & Without definitive diagnosis & 39 \\
\hline
\end{tabular}

${ }^{1}$ Rheumatology, Instituto Portugues De Reumatologia, Lisbon, Portugal

Full list of author information is available at the end of the article

(c) 2014 Fernandes et al; licensee BioMed Central Ltd. This is an Open Access article distributed under the terms of the Creative Commons Attribution License (http://creativecommons.org/licenses/by/4.0), which permits unrestricted use, distribution, and reproduction in any medium, provided the original work is properly cited. The Creative Commons Public Domain Dedication waiver (http://creativecommons.org/publicdomain/zero/1.0/) applies to the data made available in this article, unless otherwise stated. 
were also analyzed. All of these patients are registered in SPR database (REUMA.PT).

\section{Conclusion}

It's clear that JIA is a group of several joint diseases that start in children and may continue to affect these patients throughout their adult life. A significative group of this patients can be classified as juvenile spondyloarthritis $(75 / 206=36 \%)$ This analysis shows that JIAs are not a benign and self-limiting disease group, being essential to ensure the proper continuity of rheumatologic care for these patients in adulthood, preferably using a common language and approach to classify and treat these patients.

\section{Disclosure of interest}

None declared.

\section{Authors' details}

${ }^{1}$ Rheumatology, Instituto Portugues De Reumatologia, Lisbon, Portugal.

${ }^{2}$ Bioinformatician, Sociedade Portuguesa de Reumatologia, Lisboa, Portugal.

Published: 17 September 2014

doi:10.1186/1546-0096-12-S1-P193

Cite this article as: Fernandes et al:: Juvenile idiopathic arthritis: the transition to adulthood. Pediatric Rheumatology 2014 12(Suppl 1):P193.
Submit your next manuscript to BioMed Central and take full advantage of:

- Convenient online submission

- Thorough peer review

- No space constraints or color figure charges

- Immediate publication on acceptance

- Inclusion in PubMed, CAS, Scopus and Google Scholar

- Research which is freely available for redistribution

Submit your manuscript at www.biomedcentral.com/submit
C Biomed Central 